\title{
Investigating Foreign Language Teacher Anxiety Using SFL's ATTITUDE and TRANSITIVITY Systems
}

\author{
Julia Goetze, Pennsylvania State University \\ jzg5860@psu.edu
}

\begin{abstract}
This study investigates language teachers' verbal construals of classroom anxiety and its cognitive precursors by drawing on the TRANSITIVITY and ATTITUDE systems in systemic functional linguistics (Martin \& White, 2005) and integrating them with appraisal theory in cognitive psychology (Smith \& Lazarus, 1993). Three collegiate-level German teachers in a CLIL-like context participated in a two-week classroom observation sequence, which included 8 in-depth, semi-structured interviews that employed stimulated recall methodology by way of recorded classroom observations. Transcribed interview data were examined using both TRANSITIVITY analysis to capture experiential meanings and a multi-step TRANSITIVITY and ATTITUDE analysis to capture both emotional meanings and cognitive appraisals simultaneously. Findings revealed individual patterns of verbal construals of anxiety for each participant. The multi-step analysis uncovered discernible patterns for the verbal construal of cognitive appraisals that are strongly associated with both participants' feelings of anxiety and their beliefs about the nature of language teaching. Based on these findings, a new system network for the description and approach to the analysis of foreign language (FL) teacher emotions is proposed and implications of the findings for future research into teacher emotions and beliefs, as well as for teacher training, emotional well-being, and foreign language pedagogy research are discussed.
\end{abstract}

Keywords: teacher emotions, anxiety, appraisal theory, systemic functional linguistics 
In recent years, the FL teacher has received increased research attention (e.g., Dios Martínez Agudo, 2018; Mercer \& Kostoulas, 2018), slowly beginning to redress the imbalance between studies focused on learners and studies focused on teachers in the field of second language acquisition (SLA). The emergent body of research focuses mainly on teacher cognitions (e.g., Burns, Freeman, \& Edwards, 2015), teacher identity (e.g., Wolff \& DeCosta, 2017), and teacher motivation (e.g., Dörnyei \& Kubanyiova, 2014), while investigations of other individual differences (IDs), such as teacher emotions, are still scarce. This is surprising, considering that (student) anxiety is one of the most researched ID in SLA and it has been claimed that teachers are equally affected by their emotions as their students (e.g., Horwitz, 1996). This may especially be true in content-based instruction (CBI) or content and language integrated learning and teaching (CLIL) contexts, for which specialized teacher training is often lacking and instructors need to independently develop their own content and linguistic competence, acquire best pedagogical practices, and implement them within unique institutional contexts. Coupling these professional demands with personal beliefs and attitudes towards CLIL instruction, as well as with students' educational and affective needs in the classroom seems to suggest that teachers' emotional sensitivity and emotion management are essential and demanding components of the teacher role in CLIL/CBI program (Pappa et al., 2017). The goal of this study is to contribute to the growing body of research on FL teacher emotions by exploring FL teacher anxiety in a CLIL-like collegiate-level context through a discourse-analytical framework that integrates systemic functional linguistics (SFL) and cognitive psychology.

\section{LITERATURE REVIEW}

\section{What is FL (Teacher) Anxiety?}

While anxiety is one of the most well-studied affects in education, psychology, and SLA, it has also been characterized as a challenging variable due to its multifacetedness (e.g., Scovel, 1978). This characterization is rooted in the existence of four paradigms of emotion research in the field of psychology, each of which developed their unique definition and understanding of the nature of anxiety. That is, the psychoanalytical paradigm defines anxiety as an affective state, which has the potential to induce physiological and behavioral changes (e.g., Freud, 1895/1924), while the biological paradigm understands anxiety to be chemical and neural responses to stimuli in the brain, which ultimately result in behavioral manifestations (e.g., Damasio, 1999). In the behavioral paradigm, emotions are understood as distinct patterns of physical reactions and expressive behaviors with functional significance (Barlow, 1988), though researchers do not agree whether anxiety is a distinct or a hybrid emotion (e.g., Izard, 1977; Plutchik, 1980). In the cognitive paradigm, researchers focus on information-processing sequences, claiming that an individual's cognitive evaluation of a situation leads to a distinct emotional feeling state such as anxiety (Sutton \& Wheatley, 2003). In other words, while the first three paradigms identify anxiety as an emotional process and/or phenomenon that manifests itself in behavior or physiological symptoms, researchers in the cognitive paradigm understand anxiety as an emotional product manifesting itself through cognitive activity.

In the field of SLA, Scovel's (1978) seminal paper critiqued the imprecise use of this plethora of anxiety definitions, which has led to conflicting research findings. Consequently, multiple domain-specific definitions of foreign language anxiety (FLA) have been introduced, two of which are still frequently used today. The first defines FLA as "a distinct complex of self-perceptions, beliefs, feelings, and behaviors related to classroom language learning arising from the uniqueness of the language learning process" (Horwitz et al., 1986, p. 128). The second defines FLA as "an undifferentiated, negative affective response to some experience in language class" (MacIntyre \& Gardner, 1991, p. 297). While the first definition is exclusively applicable to a student population, specifying that FLA is unique to language "learning", rather than language "teaching", the latter more broadly references an "experience in language class", which may be applicable to students and teachers alike. Despite the clear difference, both definitions appear to be rooted in the cognitive research paradigm, whereby anxiety is either an emotional "response" (MacIntyre \& Gardner, 1991) or "result" from the "cognitive process" of language learning (Horwitz et al., 1986). 
A look at the few existing FL teacher anxiety studies, however, reveals that a clear definition of anxiety as it relates to teachers is lacking. Kim and Kim (2004) do neither explicitly define teachers' FLA nor conceptualize it to be an emotional result of cognitive processes. However, they clearly identify "worry" and "beliefs" (p. 176) - both cognitive processes - as the precursor for teachers' anxious experience. Similarly, Merç (2011) only offers the term "concerns" (p. 84) to describe his understanding of teacher anxiety in the language classroom. It may be argued that this term also refers to a cognitive process triggered by stimuli such as "students and class profiles, classroom management, teaching procedures, being observed, mentors" (ibid., p. 91), all of which lead to an emotional experience of anxiety, but this is not clear. Tum (2014) connects the feeling of anxiety to the "awareness" that teachers have of the "challenges and responsibilities" in their profession (p. 631). Put differently, the evaluation of the various aspects and demands of the teaching profession result in teachers' feelings of anxiety in the language classroom.

Overall, despite the lack of explicitness, these few existing studies suggest that FL teacher anxiety is assumed to be linked to cognitive processes related to FL teaching, thereby warranting both an explicitly cognitive approach to the study of anxiety and a joint examination of both the feeling state and its cognitive precursors.

\section{Appraisals: The Cognitive Precursors of Anxiety}

The concept of appraisal and its role in the emotional process has existed in psychological thought since the 1940s (e.g., Grinker \& Spiegel, 1945; Janis, 1951) and was systematically theorized in the 1960s. Arnold (1960) first defined an appraisal as the evaluation of the significance of a stimulus by an individual. Developing her ideas further, Lazarus (1966) postulated that appraisals include both selfinvolved as well as environment and coping-related evaluations. Their theorizations laid the groundwork for the basic premise of appraisal theory today, which gained broad recognition in the 1980s, when the preferred paradigm for emotion research in psychology shifted from behaviorism to cognition (Ellsworth, 2013). Since then, appraisal researchers claim that an emotion is a "reaction to $[\ldots]$ an organism (person) - environment relationship" (Smith \& Lazarus, 1990, p. 614), arguing that an emotion is elicited when the meaning of a situation is evaluated with regard to its significance for personal well-being along a number of dimensions, which serve as the discrete elements in a cognitive sequence. The process by which values are produced for each evaluative dimension is termed "appraisal" (Moors et al., 2013).

While appraisals are clearly defined, appraisal theorists have produced multiple theoretical frameworks with varying appraisal dimensions (for an excellent overview see Ellsworth \& Scherer, 2003). Following an in-depth review of these existing frameworks and clarifying the conceptual distinction between "knowledge" and "appraisal", which had led to misconceptions of appraisal dimensions in numerous frameworks, psychologists Smith and Lazarus (1988) identified six universal appraisal dimensions that directly evaluate meaning in form of the personenvironment relationship and are therefore understood to be "true appraisal processes" (p. 289). These six dimensions are (1) motivational relevance, evaluating the extent to which an encounter touches upon personal goals and concerns, (2) motivational congruence, evaluating the extent to which a situation is consistent or inconsistent with one's personal goals and desires, (3) accountability, determining the direction and focus of the emotional response (e.g., whether oneself or someone else receives credit or blame for the harm or benefit resulting from the situation), (4) problem-focused coping potential, evaluating whether and how the person is able to physically manage or control the demands of the encounter, (5) emotion-focused coping potential, evaluating the perceived prospects of adjusting psychologically to the situation, and (6) future expectancy, evaluating the perceived possibilities for changes in the psychological situation that could make the situation more or less motivationally congruent.

Based on their theoretical work and the basic premise that different combinations of appraisals elicit distinct emotions (Scherer et al., 2001), Smith and Lazarus (1990) hypothesized that the evaluation of a situation as motivationally relevant, motivationally incongruent, and low in terms of emotion-focused coping potential results in an anxious feeling state. Their hypothesis was subsequently tested and validated across various educational contexts with both student and teacher populations (e.g., Ellsworth \& Smith, 1988; Goetze, 2018; Lazarus \& Smith, 1993). 


\section{Evaluative Language: The Verbal Construal of Emotions and Cognitions in Discourse}

Evaluative language is defined as language that is both subjective and located within a societal value system and which indexes the act of evaluation and attitude towards a person, situation, or other entity (Du Bois, 2007; Hunston, 2011). It ideally lends itself to the investigation of how internal and subjective experiences, such as anxiety and the assignment of personal meaning to a specific set of evaluative dimensions, are verbalized, since it captures both the process of evaluation and the expression of a subjective or personally meaningful attitude. However, within this area of inquiry, most researchers either choose to study particular language resources that are used to express evaluation and emotion (e.g., Biber, 2006; Hyland \& Tse, 2005), or they compare and contrast amounts and types of evaluative language in different collections of texts (e.g., Charles, 2006). In other words, they focus mainly on analyzing linguistic expressions of evaluation in different text types, disregarding the process of how these meanings are assigned.

Under the term APPRAISAL, Martin and White (2005) introduce a system of meanings, which allows researchers to close this gap. Their evaluation-focused system has often been called the most comprehensive and well-theorized analytical framework for the description of how emotionrelated meaning is made and assigned to an object through linguistic forms (Hunston, 2011). It is rooted in systemic functional linguistics (SFL) (Halliday \& Matthiessen, 2004; Matthiessen, 1995), where it is located on the discourse semantic level and encodes both emotional and attitudinal meanings, which are realized through a plethora of lexicogrammatical structures. For example, emotional meanings related to anxiety may be realized as an adjective ("I feel anxious") or as a nominal group ("My paralyzing anxiety is taking control of my mind and body"), which is indicative of the range of lexical and/or grammatical choices speakers can make to realize the same meaning.

More specifically, APPRAISAL is divided into three interacting sub-domains: ATTITUDE, ENGAGEMENT, and GRADUATION, of which only the domain of ATTITUDE is concerned with how feelings are construed. ATTITUDE is further subcategorized into affect, which deals with emotional reactions and emotional states (e.g., un/happiness, in/security, and dis/satisfaction); judgment, which deals with assessments of discourse participants' behavior (e.g., the extent of its ethical and truthful nature) with regards to social values and various normative principles (e.g., the degree of participants' normality, tenacity, and capability); and appreciation, which deals with interpersonal reactions to and evaluations of values of things, including natural phenomena (e.g., its perceived quality, impact, and value).

While ATTITUDE is concerned with the verbal construal of emotional meanings (e.g., anxiety, enjoyment, pride), it does not capture the target to which the emotional meaning is assigned (e.g., a student, class content, an activity type, the use of a specific language skill). However, it is crucial to analyze both meanings simultaneously, in order to trace the appraisal process of assigning meaning to different evaluative dimensions. In SFL, the targets to which emotional meanings are assigned are encoded in the TRANSITIVITY system (Martin \& White, 2005), which captures experiential meanings or linguistic construals of a teacher's subjective classroom reality, such as age, number, and type of students, proficiency level, classroom set-up, available resources, the pedagogical approach, or type of student interaction.

Since TRANSITIVITY encodes reality, such as the presence of people and objects and their actions, is it subcategorized into process types (i.e., verbal groups), their associated process participants, as well as the process circumstances (i.e., when, where, how, or under what circumstances an experience or action takes place), all of which are defined in detail in Table 1.

Because SFL postulates that attitudinal and experiential meanings are mapped simultaneously onto a speech act, the what and how of a personally meaningful evaluation and feeling can be traced and described at the same time. Therefore, Martin and White's (2005) framework affords the investigation and description of how and what kind of emotional and evaluative meanings are construed and shared overtly and covertly in language, thereby aligning with the assumptions of a cognitive understanding of anxiety, namely that the emotion results from a distinct pattern of a personally meaningful cognitive evaluation of classroom reality. 
Table 1. Subcategories of the TRANSITIVITY System with Definitions

\begin{tabular}{|c|c|c|}
\hline Process types & Process participants & Process circumstances \\
\hline material & Actor (doer of an action) & extent \\
\hline $\begin{array}{l}\text { processes of doing and } \\
\text { concrete action }\end{array}$ & Goal (receiver of an action) & the duration and frequency of a process \\
\hline mental & Senser (conscious human) & location \\
\hline $\begin{array}{l}\text { processes of thinking and } \\
\text { feeling }\end{array}$ & $\begin{array}{l}\text { Phenomenon (that which is felt, } \\
\text { thought, or perceived) }\end{array}$ & the time and place of a process \\
\hline behavioral & Behaver (conscious being) & manner \\
\hline $\begin{array}{l}\text { processes between doing and } \\
\text { thinking/feeling (i.e., dreaming, } \\
\text { looking) }\end{array}$ & $\begin{array}{l}\text { Behavior (restatement of the } \\
\text { process) }\end{array}$ & $\begin{array}{l}\text { the quality, comparison, and degree of a process } \\
\text { cause }\end{array}$ \\
\hline verbal & Sayer (does of the process) & the reasons for a process \\
\hline processes of verbal action & $\begin{array}{l}\text { Receiver (receiver of the } \\
\text { process) } \\
\text { Verbiage (that what is } \\
\text { verbalized) }\end{array}$ & $\begin{array}{l}\text { contingency } \\
\text { the conditions under which a process takes place }\end{array}$ \\
\hline existential & Existent (a phenomenon & matter \\
\hline processes of existing & followed by "there is / there are") & the applicability of the process \\
\hline $\begin{array}{l}\text { relational } \\
\text { existence of things in relation } \\
\text { to other things (e.g., attributes } \\
\text { or identities) }\end{array}$ & $\begin{array}{l}\text { Carrier (a phenomenon) } \\
\text { Attribute (a quality, classification, } \\
\text { or descriptive epithet assigned to } \\
\text { the Carrier) }\end{array}$ & \\
\hline
\end{tabular}

Note. cf. Martin, Matthiessen and Painter (2010). The authors suggest additional circumstance types, which are left out here, as they did not occur in the data.

Based on the research discussed above, this study investigates the following research questions:

RQ1: How do FL/L2 teachers in a CLIL-like context verbally construe their experiences of anxiety?

RQ2: How are cognitive appraisals verbally construed when anxiety is discussed?

\section{METHODOLOGY}

\section{Context and Participants}

The study was conducted with three graduate student teachers in a German Department in a North American collegiate context over a multi-week period in the spring semester 2017. The department's undergraduate curriculum does not differentiate between language and content courses, but instead is committed to developing students' L2 literacy by promoting integrated language and content learning across a variety of private and public discourses at all stages of students' development through genre-, content-, and task-based instruction. The language of instruction at all levels of the curriculum is German.

All three participants were trained in the department's pedagogical approach, regularly engaged in curriculum development, and had previous teaching experience at the time of data collection. They were selected via convenience sampling (Mackey \& Gass, 2011). What follows are brief portraits of the participants, all of whom are assigned pseudonyms.

\section{Julius}

Julius is a 29-year-old male American. He is a native speaker of English and his first foreign language is German, 
which he started learning at age 10 in a language immersion context during his summer break. He continued acquiring the language in this context for seven consecutive summers. Besides German, Julius has also received five and a half years of foreign language instruction in French in middle school, high school, and graduate school and one year of Arabic instruction in college. He has spent most of his life in the US. However, he completed a one-year Fulbright teaching assignment in Austria at age 22, where he taught English at the high school level in three different schools. At the time of the study, Julius was in his third year of graduate school. He was teaching an intermediate-level German class, which was the third class he taught in the particular instructional context.

\section{Sarah}

Sarah is a 28 -year-old female German. She is a native speaker of German and her first foreign language is English, which she started learning in fifth grade at age 11. Besides English, she also received formal FL instruction in French for five years in high school and for an additional five years in college. Sarah grew up and lived in Germany until she was 25 years old, completing her bachelor's degree and obtaining a master's level teaching degree in teaching English and French as a foreign language there. At age 25, she moved to the United States to pursue her graduate education in German studies. As a graduate student, she worked as a language instructor of German at two separate universities. At the time of data collection, Sarah was in her first semester of teaching in the specified research context, although her overall FL teaching experience amounts to eight semesters.

\section{Walter}

Walter is a 24-year-old male American. He is a native speaker of English and his first and only foreign language is German, which he started learning in second grade at age 8 . He studied German in high school for four years and majored in it at college. Walter has lived in the United States for most of his life but has studied abroad in Germany for 14 months collectively during his high school, undergraduate, and graduate student career. Although
Walter majored in German in college, he first taught the language in graduate school. At the time of the study, Walter was in his second semester of teaching an introductory-level German class, which is the class consecutive to the one that he had taught the previous semester.

\section{Procedure and Data}

The data for this study consist of a series of six video-taped 50-minute classroom sessions and eight 15 to 25-minute, audio-recorded, semi-structured interviews for each participant, which were collected during the spring semester 2017. The interview protocols were developed based on Seidman's (1991) three-stage interview methodology, which first establishes the context of a person's experience of the phenomenon under study (i.e., anxiety), then reconstructs the details of the experience within the context it occurred, and lastly encourages reflection on the personal meaning of the experience. The first interview stage occurred approximately one week before the observation sequence, while the last stage took place approximately three weeks after the observation sequence had concluded. The second interview stage took place after each of the six classroom sessions and utilized stimulated recall methodology (Gass \& Mackey, 2013). That is, participants were shown video excerpts of their teaching and were asked to describe the classroom situation in their own words, and to talk about their feelings and thoughts during that situation. Here, video stimuli of positive and negative classroom moments were counterbalanced by asking participants to identify both challenging and enjoyable classroom situations during the interview sessions, in order to both maintain the participants' level of comfort and not to prompt the use of repetitive and monotonous language. All interviews were subsequently transcribed and excerpts in which anxiety is construed as a feeling state were preselected for analysis by the researcher and the pre-selection was confirmed by the participants. A total of three excerpts per participant were identified, which are considered uniform in length (mean length in words/excerpt: $M_{\text {Julius }}=$ $\left.163.67, M_{\text {Sarah }}=185.33, M_{\text {Walter }}=171.33\right)$. To ensure that participants were not limited in their expression of thoughts and feelings, all participants were interviewed in their respective mother tongues. 
Sample Interview Excerpt: Julius

Interviewer: $\quad$ Yeah - I think they were talking about Google Translate and that you can't use Google Translate - or why.

Julius: Yes.

Interviewer: $\quad$ Or you were explaining why they shouldn't use that.

Julius: $\quad$ Yes. Exactly. And because that's such a focal point of our curriculum, I wanted to jump on that and spend half a second talking about -

Interviewer: stress that again?

Julius:

And, actually, then just before that was a moment where I felt - I

felt a little bit guilt because I let my momentary irritation show

through. Because I feel as though students of this caliber should

know not to use Google Translate by now, if they are - if they are

looking for more than a gist reading. I feel like they should know, if they are looking up a word that they don't know in a new context, they have the resources to do that and so - I - I hope that the student in that case didn't interpret what I said and the way I said it as being angry or anything like that. I try to avoid that coming through. And that potential misapprehension makes me nervous sometimes.

Sample Interview Excerpt: Sarah

Interviewer: $\quad$ Uh - I don't know whether you noticed that, that you bit your lips both times -

Sarah: (laughs)

Interviewer: $\quad$ - while - while you either wait for her [a female student] to say something or while she reads. What was in these two moments - what were your thoughts?

Sarah: Good question. So I think, I'm doing this subconsciously the entire time, that I bite my lips or press them together like that. I do this all the time. So, regarding this student - I think, I have somehow already when I call on her to read a longer and more complicated text - I do worry a little bit, because I know, that she has difficulties with that. She is great in writing, but when it comes to speaking or listening comprehension - that's where she has quite some problems. But I have to call on her regardless, because otherwise I won't get anything from her. So, she never contributes anything voluntarily. And I don't know - partly it is probably uncomfortable for me that I have to put her into this situation. But on the other hand, I also have the feeling that I need to do it regardless, in order to help her advance.

Sample Interview Excerpt: Walter

Interviewer: $\quad[\ldots]$ Can you like describe to me what happened there?

Walter: $\quad$ I just -

Interviewer: What went on in your head?

Walter: $\quad$ I was thinking - I was not - I just - The document was in a different folder and I was just like too nervous to notice that. 
Interviewer: $\quad$ Uh-hum. And then you just like scrolled and - then? I mean - I'm asking because you also like - You then started commenting on what music you listen to -

Walter: Well, because I know that they are looking at the screen too. They can see what I'm searching through. So, I like - You feel like all eyes are on you. And using your personal computer in instruction like that - It's like everything is so dependent on the comp- - on you operating the computer. Yeah, exactly.

Interviewer: $\quad$ So, you were really nervous about what exactly?

Walter: I was trying to get back to that document.

Interviewer: that you had just closed, right?

Walter:

Interviewer:

Right - I had just closed. And I just couldn't find it.

Yeah. And did you get nervous because you knew it was there and you just couldn't find it in the computer?

Walter: $\quad$ Well, it's like - I mean like - you know - I'm observing myself - I'm being observed by my students and I'm being observed by you. So that's like a triple - that's thrice over. I literally had my own eye, their eyes, and your mechanical eye all on me. So, that's like threefold - like being under - unter der Lupe [German for: under the magnifying glass] (laughs). It's not like - It's kind of a new when looking through documents on a computer becomes something nerve wrecking.

\section{Analytical Procedure}

To answer RQ1, the analysis was guided by a coding scheme that is rooted in SFL's TRANSITIVITY system. Since experiential meanings are realized at the clause level, where each clause functions as a representation of meaning (Halliday \& Matthiessen, 2004), the clause served as the unit of analysis.
To prepare the data, interview transcripts were first broken down into Analysis of Speech units (AS-unit) (Foster et al., 2000), before data were further divided into clauses. Next, data were coded for process type, process participants, and process circumstances (Figure 1) and frequency counts were examined for trends in verbal construals of experiential meanings across participants, as well as for similarities and differences between them.

Figure 1. Sample TRANSITIVITY Coding

\begin{tabular}{|c|c|c|c|c|}
\hline$\underline{\text { Speaker }}$ & Utterance & $\underline{\text { Process }}$ & $\underline{\text { Participants }}$ & Circumstances \\
\hline \multirow[t]{3}{*}{ Julius } & $\begin{array}{l}\text { And, actually, then just } \\
\text { before that there was a } \\
\text { moment }\end{array}$ & existential & $\begin{array}{l}\text { Existent: a } \\
\text { moment }\end{array}$ & $\begin{array}{l}\text { location (time): } \\
\text { then, just before } \\
\text { that }\end{array}$ \\
\hline & $\begin{array}{l}\text { where I felt - I felt a little } \\
\text { bit guilt }\end{array}$ & $\begin{array}{l}\text { mental process } \\
\text { (affection) }\end{array}$ & $\begin{array}{l}\text { Senser: I } \\
\text { Phenomenon: } \\
\text { guilt }\end{array}$ & $\begin{array}{l}\text { manner } \\
\text { (degree): a little } \\
\text { bit }\end{array}$ \\
\hline & $\begin{array}{l}\text { because I let my } \\
\text { momentary irritation } \\
\text { show through. }\end{array}$ & material & $\begin{array}{l}\text { Actor: I } \\
\text { Goal: my } \\
\text { irritation }\end{array}$ & $\begin{array}{l}\text { cause (reason): } \\
\text { because... }\end{array}$ \\
\hline
\end{tabular}


To answer RQ2, the analysis was guided by a coding scheme that is rooted in both SFL's TRANSITIVITY and ATTITUDE systems. To prepare the data for analysis, the
TRANSITIVITY elements that correspond to the six cognitive appraisal dimensions were identified (Table 2) and formed the unit of analysis.

Table 2. TRANSITIVITY components and corresponding cognitive appraisal dimensions

\begin{tabular}{ll}
\hline Cognitive appraisal dimension & TRANSITIVITY component \\
\hline $\begin{array}{l}\text { Motivational relevance } \\
\text { the extent to which an encounter touches upon personal }\end{array}$ & Process participants of material and mental processes \\
goals and concerns. & Attribute of relational processes \\
$\begin{array}{l}\text { Motivational congruence } \\
\text { the extent to which a transaction [or interaction] is consistent }\end{array}$ & \\
or inconsistent with what one wants & Process participants of mental processes \\
$\begin{array}{l}\text { Accountability } \\
\text { the direction and focus of an emotional response }\end{array}$ & \\
$\begin{array}{l}\text { Emotion-focused coping potential } \\
\text { the degree to which a person is able to adjust }\end{array}$ & Mental processes \\
psychologically or mentally to the situation & \\
$\begin{array}{l}\text { Problem-focused coping potential } \\
\text { the degree to which a person is able to act upon the } \\
\text { demands of the situation }\end{array}$ & \\
$\begin{array}{l}\text { Future expectancy } \\
\text { the perceived possibilities [...] for changes in the } \\
\text { psychological situation that could make the situation more or } \\
\text { less motivationally congruent }\end{array}$ & \\
\hline
\end{tabular}

The overview in Table 2 indicates that some cognitive appraisal dimensions correspond to the same TRANSITIVITY element. For example, emotion-focused coping potential and future expectancy are both evaluating mental processes. However, coping potential evaluates ability, while future expectancy assesses possibility. Similarly, motivational congruence and motivational relevance are both linked to process participants but evaluate the extent of intensity and the extent of consistency respectively. These nuances are captured by the coding scheme.
In a last step, selected TRANSITIVITY elements were coded for the evaluative meaning using SFL's ATTITUDE system, differentiating between feeling types (i.e., affect, judgment, appreciation), as well as between each type's subcategories (e.g., in/security, un/happiness, etc.). To facilitate coding, the coding scheme included information about the source and target of the evaluation, the lexicogrammatical realization of the appraisal, as well as the construed cognitive appraisal dimension (Figure 2). 
Figure 2. Sample TRANSITIVITY/ATTITUDE Coding

\begin{tabular}{|c|c|c|c|c|c|c|c|c|}
\hline \multirow[t]{2}{*}{ UTTERANCE } & \multirow[t]{2}{*}{$\frac{\text { TRANSITIVITY }}{\text { (WHAT?) }}$} & \multicolumn{3}{|c|}{$\frac{\text { ATTITUDE }}{\text { (HOW?) }}$} & \multicolumn{2}{|c|}{$\frac{\text { SOURCE / TARGET }}{\text { (WHO/WHAT?) }}$} & \multirow{2}{*}{$\begin{array}{l}\text { LEXICO- } \\
\text { GRAMMATICAL } \\
\underline{\text { REALIZATION }}\end{array}$} & \multirow[t]{2}{*}{$\begin{array}{l}\text { COGNITIVE } \\
\text { DIMENSION }\end{array}$} \\
\hline & & Type & Cate. & $+1-$ & $\begin{array}{l}\text { Source / } \\
\text { Appraiser }\end{array}$ & $\begin{array}{l}\text { Target / } \\
\text { Appraised }\end{array}$ & & \\
\hline $\begin{array}{l}\text { And that potential } \\
\text { misapprehension makes me } \\
\text { nervous sometimes. }\end{array}$ & Agent & $\mathrm{AFF}$ & SEC & - & $\begin{array}{l}\text { Actor } \\
\text { (Julius) }\end{array}$ & $\begin{array}{l}\text { Agent } \\
\text { (source of his } \\
\text { nervous } \\
\text { feeling state) }\end{array}$ & $\begin{array}{l}\text { potential } \\
\rightarrow \text { modalization } \\
\text { (probability) } \\
\text { modal adjunct } \\
\text { misapprehension } \\
\rightarrow \text { lexis (nominal } \\
\text { group) }\end{array}$ & $\begin{array}{l}\text { motivational } \\
\text { incongruence }\end{array}$ \\
\hline & Attribute & AFF & SEC & - & $\begin{array}{l}\text { Actor } \\
\text { (Julius) }\end{array}$ & Carrier & $\begin{array}{l}\text { nervous } \\
\rightarrow \text { lexis (adjective) }\end{array}$ & feeling state \\
\hline
\end{tabular}

\section{RESULTS}

\section{Verbal Construal of Teachers' Anxious Experiences}

The results of the TRANSITIVITY analysis are displayed in the tables below. Table 3 shows frequency counts of process types, while Table 4 displays process circumstances across participants.
The results in Table 3 reveal that all three participants use material, mental, and relational processes most frequently, indicating that participants are focusing primarily on both cognitive and affective, as well as concrete actions, while also describing their perceptions of what and/or whom is present in an anxiety-inducing classroom situation.

Table 3. Frequency Counts of Process Types for All Participants

\begin{tabular}{|c|c|c|c|c|c|c|c|}
\hline \multirow[t]{2}{*}{ Participant } & \multirow[t]{2}{*}{ Excerpt } & \multicolumn{6}{|c|}{ Process type } \\
\hline & & Material & Mental & Relational & Behavioral & Verbal & Existential \\
\hline \multirow[t]{4}{*}{ Julius } & 1 & 6 & 5 & 3 & 0 & 0 & 1 \\
\hline & 2 & 5 & 10 & 4 & 0 & 0 & 0 \\
\hline & 3 & 7 & 3 & 2 & 0 & 4 & 0 \\
\hline & Total & 18 & 18 & 9 & 0 & 4 & 1 \\
\hline \multirow[t]{4}{*}{ Sarah } & 1 & 9 & 14 & 8 & 2 & 5 & 0 \\
\hline & 2 & 3 & 4 & 8 & 0 & 0 & 1 \\
\hline & 3 & 11 & 4 & 5 & 1 & 0 & 0 \\
\hline & Total & 23 & 22 & 21 & 3 & 5 & 1 \\
\hline \multirow[t]{4}{*}{ Walter } & 1 & 7 & 5 & 12 & 1 & 0 & 0 \\
\hline & 2 & 1 & 8 & 16 & 0 & 3 & 1 \\
\hline & 3 & 4 & 8 & 5 & 0 & 0 & 0 \\
\hline & Total & 12 & 21 & 33 & 1 & 3 & 1 \\
\hline Total & & 53 & 61 & 63 & 4 & 12 & 3 \\
\hline
\end{tabular}


Similarly, the results in Table 4 show an overall tendency to use circumstances of location and manner (i.e., where and how actions are carried out or take place) most frequently across all participants. However, a closer look at both tables reveals individual patterns of how classroom realities are perceived and verbally construed for each participant.

Table 4. Frequency Counts of Process Circumstances for All Participants

\begin{tabular}{|c|c|c|c|c|c|c|c|c|}
\hline \multirow[t]{2}{*}{ Participant } & \multirow[t]{2}{*}{ Excerpt } & \multicolumn{7}{|c|}{ Process circumstance } \\
\hline & & Extent & Location & Manner & Cause & Contingency & Matter & Total \\
\hline \multirow[t]{4}{*}{ Julius } & 1 & 0 & 3 & 1 & 3 & 2 & 0 & 9 \\
\hline & 2 & 1 & 3 & 0 & 4 & 3 & 0 & 11 \\
\hline & 3 & 1 & 6 & 3 & 1 & 1 & 0 & 12 \\
\hline & Total & 2 & 12 & 4 & 8 & 6 & 0 & 32 \\
\hline \multirow[t]{4}{*}{ Sarah } & 1 & 3 & 9 & 14 & 3 & 3 & 0 & 32 \\
\hline & 2 & 3 & 6 & 6 & 1 & 5 & 0 & 21 \\
\hline & 3 & 5 & 2 & 7 & 5 & 5 & 0 & 24 \\
\hline & Total & 11 & 17 & 27 & 9 & 13 & 0 & 77 \\
\hline \multirow[t]{4}{*}{ Walter } & 1 & 0 & 4 & 6 & 1 & 1 & 0 & 12 \\
\hline & 2 & 2 & 7 & 9 & 3 & 2 & 3 & 26 \\
\hline & 3 & 1 & 9 & 2 & 0 & 0 & 1 & 13 \\
\hline & Total & 3 & 20 & 17 & 4 & 3 & 4 & 51 \\
\hline Total & & 16 & 49 & 48 & 21 & 22 & 4 & 160 \\
\hline
\end{tabular}

Julius focuses on himself and his students' actions, emotions and thoughts when he talks about anxietyinducing moments during language instruction. This is evident in both his frequent use of material and mental processes (e.g., "I felt guilt", "I hope", "I wanted to talk”), as well as his use of "I", "my students/they", and "we" as actors to which these processes are assigned. More specifically, he details actions that exemplify the individual or collaborative classroom activities (e.g., "they look up a word", "we work with a text") and reflects on his feelings, his expectations for his own or students' behavior (e.g., "I feel like they should know"), as well as on the manners and reasons for his own instructional behaviors (e.g., "I try to avoid that [being angry] coming through"). Additionally, he uses relational processes, albeit less frequently, to express the significance of the anxiety-inducing classroom moments and how they relate to his instructional context (e.g., "because that's such a focal point of our curriculum") and his own emotions (e.g., "that makes me nervous").

Similar to Julius, Sarah also uses material, mental processes to express her classroom reality (e.g., "I call on her", "I do worry a little bit"), though she uses relational processes with higher frequency (e.g., "She is great", "She has difficulties"). While Julius focuses primarily on himself or his students in his material processes, Sarah additionally uses concrete or abstract class-related objects (e.g., an email, the clock in the classroom, sample sentences), bringing her 
pedagogic approach and student interactions with teaching materials to the fore. The focus on her instructional approach in the discussion of anxiety-inducing classroom moments is further exemplified by Sarah's frequent use of process circumstances of manner (e.g., "subconscious", "a little bit"), location (e.g., "there", "in this situation"), contingency (e.g., "in writing"), and extent (e.g., "the entire time") that almost exclusively provide more information on instructional interactions between her and the students. Another noteworthy difference to Julius is the scarcity of Sarah's explicit emotional expressions. Sarah uses mental processes almost exclusively to express her expectation for student behavior (e.g., "that they...") or to reflect on her manner of carrying out a material process (e.g., "how I ..."), rather than to express emotional states. When Sarah explicitly mentions an emotion (e.g., "I do worry a little bit", "it is uncomfortable"), she uses relational processes to link it to the instructional situation as a whole rather than making it an actor in the situation, which influences other aspects of her or the students' classroom experience.

Walter's construal of his classroom reality shows yet another distinct pattern, in which relational processes are the most frequently used process type (e.g., "it's like being under a magnifying glass"), meaning he less frequently focuses on individual classroom features (e.g., actions, people, objects) but rather on their relationship to other aspects of the situation or the situation as a whole. This holistic focus is also evident in his frequent use of "it" as a relational process participant, which is often attributed to his own cognitive or affective mental state in the situations (e.g., "it's new", “it becomes nerve wrecking"). Another indicator for Walter's holistic perception of anxietyinducing classroom situations is his varied use of process circumstances. While he most frequently details circumstances of time, location, and manner of classroom actions, he is the only study participant who made use of the full range of process circumstances in the SFL framework, indicating a keen awareness of all aspects of his classroom reality. Similar to Julius and Sarah, Walter's expression of concrete classroom actions (i.e., material processes) focuses on himself, his students, and the descriptions of teaching activities. His mental processes are more similar to Julius' in that Walter utilizes them to express both his expectation for student behavior as well as his feeling states (e.g., "I felt uncomfortable", "I felt unsure").

\section{Verbal Construal of Teachers' Cognitive Appraisals in their Accounts of Anxiety}

The combined TRANSITIVITY and ATTITUDE analysis found that all three participants construed one element of the postulated appraisal pattern of anxiety, while omitting others entirely. All excerpts indicate instances of motivational incongruence, while construals of emotionfocused coping potential are absent. Additionally, there is only one instance of motivational relevance in Walter's data, while all participants construe problem-focused coping potential, which constitutes an unexpected finding. Furthermore, Julius is the only teacher whose data shows multiple instances of future expectancy.

The construal of motivational incongruence was found in both material and relational processes, albeit it occurred in most frequently in relational processes. While all instances of motivational incongruence are realized lexically as adjectives or nominal groups, the participants make different use of attitudinal resources. That is, Julius exclusively construes meanings of affect (insecurity), whereas Sarah and Walter additionally and more frequently construe meanings of appreciation (valuation).

Walter's construal of motivational relevance was found in a sequence of three related material processes, which are all lexico-grammatically realized by the exact same verb (i.e., to observe). His repetition draws attention to and puts a special emphasis on the relevance and noteworthiness of this particular classroom event, categorizing this construal attitudinally as judgment (normality).

The construals of problem-focused coping potential were found in clauses containing material and relational processes, albeit it occurred in relational processes only once. In all instances, the participants construe attitudinal meanings of judgment (capacity), using resources of modality that are most often grammatically realized by expanding the predicator or the use of mood adjuncts. However, a closer look at the resources of modality shows noteworthy differences between the participants. That is, Julius' excerpts indicate expressions of inclination, while Sarah uses obligation, and Walter employs resources of probability most often.

Future expectancy was construed in Julius' data by means of relational, material, and mental processes. In mental processes, Julius exclusively uses attitudinal 
resources of affect (insecurity), while he draws on resources of judgments (capacity) in relational and material processes. All instances are realized lexico-grammatically by the use of future tense.

\section{DISCUSSION}

\section{The Role of Teacher Beliefs in the Linguistic Construal of Emotions}

While the results show a general pattern for the verbal construals of anxiety for all teachers, there are noteworthy nuances which are indicative of their individual teaching beliefs, classroom ideals, and attitudes towards language teaching.

\section{Julius}

In his contextualization interview, Julius claimed that working collaboratively with students was his favorite aspect of teaching and he defined successful language teaching as the ability to flexibly adjust one's pedagogical approach to the needs of the students. These beliefs are discernible in his frequent use of the collaborative "we" as participants in material and mental processes. Moreover, Julius exclusively links his students to knowledge, abilities, and teaching materials in material, mental, and relational processes, exemplifying his focus on student engagement and learning. Furthermore, the phenomena in mental processes that detail Julius' reflections on manners, causes for, and conditions under which he performs teaching behaviors could be linked to his teaching and teacher ideal. For example, his statement "I haven't figured out how - wie man sich damit umgeht [how to deal with it] - quite yet," which refers to his approach to calling on students, construes Julius' reflection on how to act in situations when students do not volunteer answers. Here, it is unclear to Julius what the students' needs are and, therefore, he is unable to act as their guide, collaboratively working with the students towards their understanding. He explicitly remarks that he does not want to discourage students by calling on them unexpectedly, which is his definition of unsuccessful teaching. His uncertainty regarding what the students need and how he can guide them in their learning seemingly leads him to experience mild anxiety.

\section{Sarah}

Sarah's favorite aspects of teaching are explaining grammar, correcting mistakes, standing in front of the class, and being able to work with and help other people. She feels a sense of pride when she witnesses her students' development of language skills and defines successful teaching accordingly. Similar to Julius, her beliefs are traceable in the data, most notably in Sarah's choice of process type. She frequently uses material, mental, and relational processes, in which she construes herself in relation to objects in the classroom, her teaching materials, or classroom events holistically. These construals are indicative of her dedication to and reflection on how to be a successful teacher. For example, "beim Reden mir fällt dann ein, wie ich es vielleicht besser ausdrücken kann [while I am talking, it occurs to me how I can maybe express it better]," refers to a teaching strategy that she applies, when she is unable to explain a grammatical concept to students. Considering that Sarah values being able to explain grammar and helping her students develop linguistic skills, this situation presents a discrepancy between her teaching ideal and experienced reality, which she described as leading her to experience mild anxiety.

\section{Walter}

Walter conceptualizes language teaching as a performance, and he defines the power dynamics in the classroom as his favorite aspect about teaching. He likes having captive audiences and speaking in front of people. He particularly enjoys it when students respect what he has to say, thereby giving him a sense of power and control, as well as reassurance in his role as the expert. In contrast, Walter does not like the high cognitive load that is involved in language teaching. Again, these ideals are traceable in his data, most notably in process types and circumstances. Walter uses predominantly relational and cognitive mental processes, a pattern that may be indicative of the high cognitive load that Walter experiences during language teaching. In addition, his varied use of circumstantial resources may also attest to high cognitive demand that language teaching places on Walter. He notices and cognitively processes teaching situations in all their facets, which places a higher cognitive demand on him than if he 
would focus on only selected circumstances, such as time and/or location. Furthermore, his frequent use of relational processes hints at Walter's conceptualization of the classroom as a space in which relations between participants are constantly (re)negotiated. The fact that Walter is very focused on his ability to perform the role of the expert is also evident in his construal of participants in material and mental processes, where actions and thoughts are exclusively focused on him as the expert in the classroom, his expectations of student behavior or what he believes students' expectations of him in that particular role are. Any deviation from his expected level of ability leads him to experience anxiety in the classroom.

\section{The Linguistic Construal of Anxiety-related Appraisals}

The results of the verbal construal of the cognitive appraisal dimensions also revealed a general pattern, which is represented in the system network below (Figure 3).

Figure 3. System Network for the Verbal Construal of Cognitive Appraisals, Featuring TRANSITIVITY and ATTITUDE Resources, as well as Lexico-grammatical Realizations

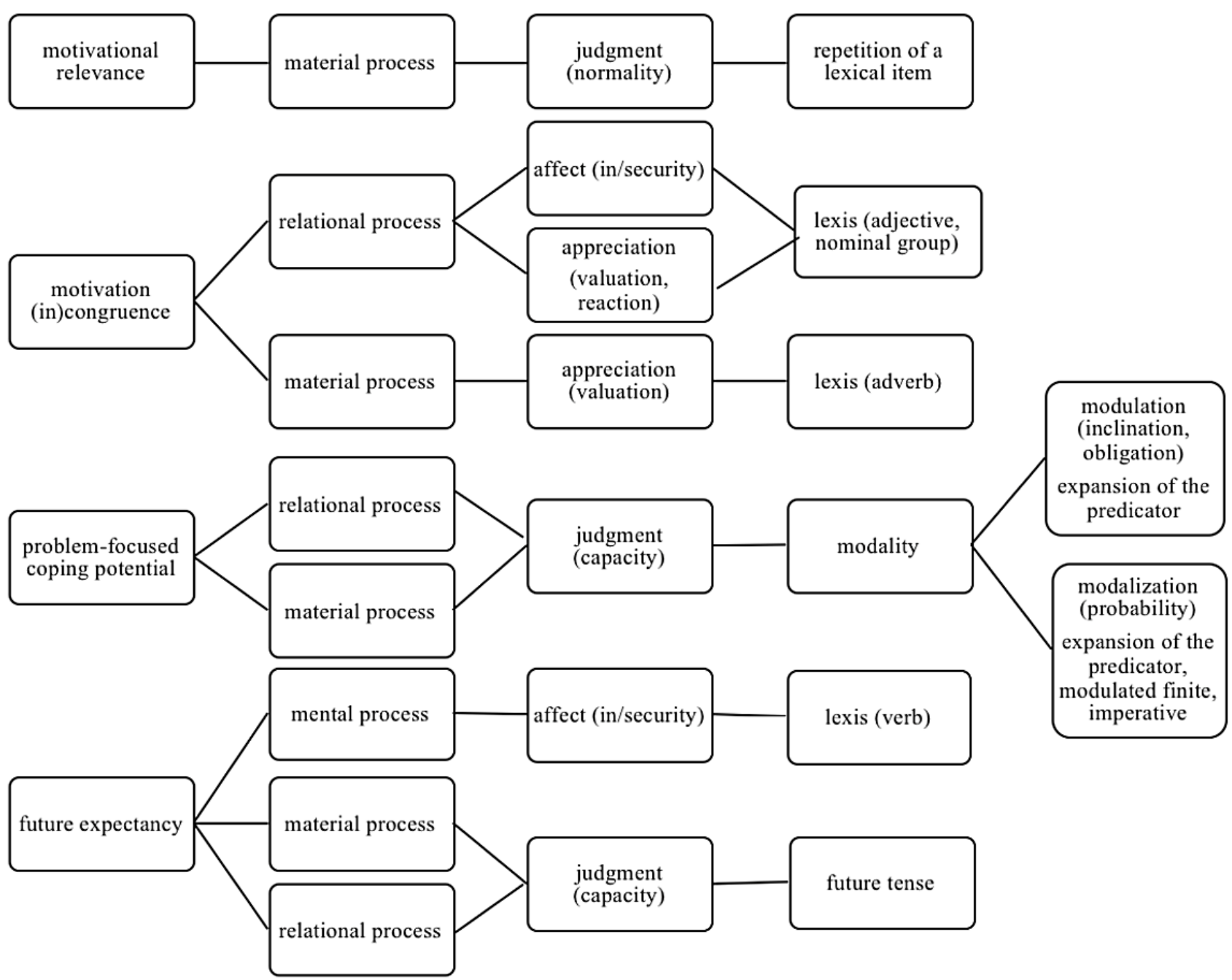


The system network illustrates the necessity to examine data from multiple angles in order to trace and unambiguously identify the cognitive appraisal dimensions that are verbally construed. For example, all four appraisal dimensions in the data set were found in material processes. Therefore, only analyzing experiential meanings would not suffice to clearly identify which cognitive appraisal dimension is construed.

The same conclusion has to be drawn for the sole analysis of evaluative meanings (the how). The system network shows that participants use all types of attitudinal resources (i.e., affect, appreciation, judgment) to construe different cognitive appraisal dimensions. As expected, resources of judgment, which evaluate behaviors, are found in the behavior-related appraisal dimension of problemfocused coping potential. However, the same resource is also found in construals of future expectancy. Similarly, resources of affect (in/security) are used in the construal of both motivational incongruence and future expectancy. In other words, the findings suggest that the sole analysis of attitudinal resources to identify cognitive appraisal dimensions might not lead to clear results either.

These findings confirm the underlying assumption that the process of cognitive appraisal involves both a target and a subjective evaluation. However, the system network also indicates that looking at experiential and attitudinal meanings simultaneously may not always suffice to clearly identify cognitive appraisal dimensions in language. For example, problem-focused coping potential and future expectancy are construed through material processes in combination with attitudinal resources of judgment (capacity). It is only in their lexico-grammatical realization, namely through the use of future tense or the system of modality, that they can be differentiated. However, only looking at the lexico-grammatical realizations of experiential and evaluative meanings related to cognitive appraisals presents a similar challenge as outlined above. That is, the sole analysis of lexico-grammatical resources does not lead to clearly discernible results either. Consequently, only when TRANSITIVITY, ATTITUDE, and their lexico-grammatical realization are considered and analyzed together are unique patterns for each cognitive dimension identifiable.

\section{The Role of Teacher Beliefs in the Linguistic Construal of Appraisals}

While the examination of lexico-grammatical realizations of the appraisal dimensions can aid in their differentiation, it also sheds light on the basis or precursor of the appraisal process. For example, all three participants mainly construed "problem-focused coping potential" through material processes and attitudinal resources of judgment (capacity), using lexico-grammatical resources of the modality system. While this finding presents a clear pattern of linguistic construal of this appraisal dimension, the choices within the modality system reveal differences between participants, which indicate their bases of their evaluation of this dimension. For example, Sarah uses primarily resources of modulation (obligation), while Walter predominantly chooses resources of modalization (probability). In other words, Sarah evaluates her ability to act upon the situation against what she believes her teacher duties, responsibilities, or obligations are, whereas Walter evaluates his capacity to act against the likelihood that he is capable to perform his role in a specific situation. Julius, on the other hand, uses resources of modulation (inclination), thereby evaluating his abilities against the ideal of how he would ideally like to act.

Researchers recently claimed that beliefs and emotions need to be investigated alongside each other as they are part of the same developmental process (e.g., Barcelos \& Ruohotie-Lyhty, 2018). The findings of this study seem to support such claims by suggesting that beliefs act as the antecedent or foundation for cognitive evaluations that lead teachers to experience emotions, such as anxiety, and that such beliefs are informing linguistic choices in the verbal construal of emotional experiences. In other words, cognitive appraisals link beliefs with emotions and are traceable in language use, which is an important finding in light of existing and emergent research on the relationship between language teachers' beliefs and emotions. More specifically, existing research claims that a state of imbalance between personal beliefs and actual events leads to experiences of cognitive dissonance, whereas an alignment of belief and reality results in a state of cognitive congruence and that both of these cognitive states cannot occur without emotional involvement (e.g., Golombek \& Johnson, 2004). In more recent empirical studies, researchers showed that cognitive congruence was linked to 
the experience of positive emotions and cognitive dissonance was linked to negative emotions (e.g., Golombek \& Doran, 2014; Kubanyiova, 2012; RuohotieLyhty, 2016), thereby showing similarities to claims in appraisal theory that motivational (in)congruence determines positive or negative feeling states (e.g., Ellsworth \& Smith, 1988). In other words, existing research already links teachers' beliefs and emotions in broad terms, using the cognitive constructs of dissonance and congruence. The findings of the current study suggest that it might be possible to break down these cognitive constructs into smaller components, namely the cognitive appraisal dimensions, thereby allowing researchers to trace the nature of the congruence or dissonance in more depth and to systematically link and trace the relationship between specific emotions to beliefs and vice versa.

Additionally, a refined understanding of how cognitions (i.e., beliefs, appraisals), affects (i.e., emotions and feeling states), and behaviors are linked might enable SLA researchers to hone the existing definitions of anxiety (e.g., a distinct complex of self-perceptions, beliefs, feelings, and behaviors), clarifying its distinctiveness as well as the systematic links between the individual components of the variable.

\section{CONCLUSION}

\section{Implications for FL Pedagogy, FL Teacher Training, and Emotional Well-being}

The findings of this study provide empirical evidence for teachers' use of their beliefs as an analytical frame to contextualize, reflect on, evaluate, and verbally construe their emotional experiences in the FL classroom. This finding is noteworthy because even though the study was carried out in the same educational context, all teachers differed in their beliefs about successful language teaching, thereby framing similar classroom experiences quite differently. However, these nuances are only discernible when beliefs are considered in the analysis and juxtaposed with the verbal construal of emotional experiences and cognitive appraisals in the classroom.

Future research could further investigate how teachers' belief systems are formed and shape the way instructors perceive classroom situations, how these perceptions are related to emotional experiences, how these emotional classroom experiences influence teaching behavior, and how all of these elements are construed in language, making explicit the dynamic interrelationships between different types of cognitions, emotions, and teaching practices (Barcelos \& Ruohotie-Lyhty, 2018; Frenzel et al., 2009). Such an approach may help to shed light on why teachers in the same institutional context experience different emotions in similar teaching situations, leading to varying levels of emotional well-being that manifest in a perceived (im)balance of positive and negative teaching-related emotions, and how these experiences shape their teaching practice longitudinally. Gregersen, MacIntyre and Olsen (2017) suggest an idiodynamic method of self-reflection, which lends itself to implementation in teacher training programs. Making explicit to future and novice teachers how their beliefs about classroom situations are formed and how or why they change has the potential to lead to more emotionally-balanced professional lives for language teachers in CLIL, CBI, as well as other contexts.

\section{Notes on the author}

Dr. Julia Goetze is an Assistant Teaching Professor at the Pennsylvania State University in the Department of Germanic and Slavic Languages and Literatures. Her research focuses on FL/L2 teacher emotions, beliefs, and identity.

\section{REFERENCES}

Arnold, M. B. (1960). Emotion and personality: Psychological aspects (Vol. 1). Columbia University Press.
Barcelos, A. M. F., \& Ruohotie-Lyhty, M. (2018).

Teachers' emotions and beliefs in second language teaching: Implications for teacher education. In J. de Dios Martínez Agudo (Ed.), Emotions in second language teaching: Theory, research and teacher 
education (pp. 109-124). Springer.

https://doi.org/10.1007/978-3-319-75438-3_7

Barlow, D. H. (1988). Anxiety and its disorders: The nature and treatment of anxiety and panic. Guilford Press.

Biber, D. (2006). Stance in spoken and written university registers. Journal of English for Academic

Purposes, 5(2), 97-116. https://doi.org/10.1016/j.jeap.2006.05.001

Burns, A., Freeman, D., \& Edwards, E. (2015). Theorizing and studying the language-teaching mind: Mapping research on language teacher cognition. The Modern Language Journal, 99(3), 585-601. https://doi.org/10.1111/modl.12245

Charles, M. (2006). The construction of stance in reporting clauses: A cross-disciplinary study of theses. Applied Linguistics, 27(3), 492-518. https://doi.org/10.1093/applin/aml021

Damasio, A. R. (1999). The feeling of what happens: Body and emotion in the making of consciousness. Harcourt Brace \& Company.

de Dios Martínez Agudo, J. (Ed.). (2018). Emotions in second language teaching: Theory, research and teacher education. Springer. https://doi.org/10.1007/978-3-319-75438-3

Dörnyei, Z., \& Kubanyiova, M. (2014). Motivating learners, motivating teachers: Building vision in the language classroom. Cambridge University Press.

Du Bois, J. W. (2007). The stance triangle. In R. Englebretson (Ed.), Stancetaking in discourse: Subjectivity, evaluation, interaction (pp. 139-182). John Benjamins. https://doi.org/10.1075/pbns.164.07du

Eggins, S. (2004). An Introduction to systemic functional linguistics. Continuum.

Ellsworth, P. C. (2013). Appraisal theory: Old and new questions. Emotion Review, 5(2), 125-131. https://doi.org/10.1177/1754073912463617

Ellsworth, P. C., \& Scherer, K. R. (2003). Appraisal processes in emotion. In R. J. Davidson, H.
Goldsmith, \& K. R. Scherer (Eds.), Handbook of affective sciences (pp. 572-595). Oxford University Press.

Ellsworth, P. C., \& Smith, C. A. (1988). Shades of joy: Patterns of appraisal differentiating pleasant emotions. Cognition \& Emotion, 2(4), 301-331. https://doi.org/10.1080/02699938808412702

Englebretson, R. (2007). Stancetaking in discourse: An introduction. In R. Englebretson (Ed.), Stancetaking in discourse: Subjectivity, evaluation, interaction (pp. 1-26). John Benjamins. https://doi.org/10.1075/pbns.164.02eng

Foster, P., Tonkyn, A., \& Wigglesworth, G. (2000). Measuring spoken language: A unit for all reasons. Applied Linguistics, 21(3), 354-375. https://doi.org/10.1093/applin/21.3.354

Freud, S. (1924). Collected papers (Vol. 1). Hogarth Press. (Original work published 1895).

Frenzel, A. C., Goetz, T., Stephens, E. J., \& Jacob, B. (2009). Antecedents and effects of teachers' emotional experiences: An integrated perspective and empirical test. In P. A. Schutz, \& M. Zembylas (Eds.), Advances in teacher emotion research (pp. 129-152). Springer. https://doi.org/10.1007/978-14419-0564-2_ 7

Frijda, N. H. (1987). Emotion, cognitive structure, and action tendency. Cognition and emotion, 1, 115143. https://doi.org/10.1080/02699938708408043

Gass, S., \& Mackey, A. (2013). Stimulated recall methodology in second language research. Lawrence Erlbaum. https://doi.org/10.4324/9781410606006

Goetze, J. (2018). Linking cognition and emotion: An appraisal study of foreign language teacher anxiety (Publication No. 10928580) [Doctoral dissertation, Georgetown University]. ProQuest Dissertations Publishing.

Golombek, P., \& Doran, M. (2014). Unifying cognition, emotion, and activity in language teacher professional development. Teaching and Teacher Education, 39, 102-111. https://doi.org/10.1016/j.tate.2014.01.002 
Golombek, P., \& Johnson, K. E. (2004). Narrative inquiry as mediational space: Examining emotional and cognitive dissonance in second language teachers' development. Teachers and Teaching: Theory and Practice, 10(3), 307-327. https://doi.org/10.1080/1354060042000204388

Gregersen, T., MacIntyre, P. D., \& Olsen, T. (2017). Do you see what I feel? An idiodynamic assessment of expert and peer's reading of nonverbal language anxiety cues. In C. Gkonou, M. Daubney, \& J.-M. Dewaele (Eds.), New insights into language anxiety: Theory, research and educational implications (pp. 110-134). Multilingual Matters https://doi.org/10.21832/9781783097722-008

Grinker, R. R., \& Spiegel, J. P. (1945). Men under stress. McGraw-Hill. https://doi.org/10.1037/10784-000

Halliday. M. A. K., \& Matthiessen, C. M. I. M. (2004). An introduction to functional grammar ( $3^{\text {rd }}$ ed.). Oxford University Press. https://doi.org/10.2307/414947

Horwitz, E. K. (1996). Even teachers get the blues: Recognizing and alleviating language teachers' feelings of foreign language anxiety. Foreign Language Annals, 29(3), 366-372. https://doi.org/10.1111/j.1944-9720.1996.tb01248.x

Horwitz, E. K., Horwitz, M. B., \& Cope, J. (1986). The foreign language classroom anxiety scale. The Modern Language Journal, 70(2), 125-132. https://doi.org/10.1111/j.1540-4781.1986.tb05256.x

Hunston, S. (2011). Corpus approaches to evaluation, phraseology and evaluative language. Routledge. https://doi.org/10.4324/9780203841686

Hyland, K., \& Tse, P. (2005). Hooking the reader: A corpus study of evaluative that in abstracts. English for Specific Purposes, 24(2), 123-139. https://doi.org/10.1016/j.esp.2004.02.002

Izard, C. E. (Ed.). (1977). Human emotions. Plenum Press. https://doi.org/10.1007/978-1-4899-2209-0

Janis, I. L. (1951). Air war and emotional stress: Psychological studies of bombing and civilian defense. McGraw-Hill. https://doi.org/10.1037/13956-000
Kim, S.-Y., \& Kim, J. (2004). When the learner becomes a teacher: Foreign language anxiety as an occupational hazard. English Learning, 59(1), 165185.

Kubanyiova, M. (2012). Teacher development in action: Understanding language teachers' conceptual change. Palgrave Macmillan. https://doi.org/10.1057/9780230348424

Lazarus, R. S. (1966). Psychological stress and the coping process. McGraw-Hill. https://doi.org/10.2307/1420698

Lazarus, R. S., \& Smith, C. A. (1988). Knowledge and appraisal in the cognition-emotion relationship. Cognition and Emotion, 2, 281-300. https://doi.org/10.1080/02699938808412701

MacIntyre, P. D., \& Gardner, R. C. (1991). Language anxiety: Its relationship to other anxieties and to processing in native and second languages. Language Learning, 41(4), 513-534. https://doi.org/10.1111/j.1467-1770.1991.tb00691.x

Mackey, A., \& Gass, S. M. (Eds.). (2011). Second language research: Methodology and design. Routledge. https://doi.org/10.4324/9781410612564

Martin, J. R., \& White, P. R. R. (2005). The language of evaluation: Appraisal in English. Palgrave Macmillan. https://doi.org/10.1057/9780230511910

Martin, J. R., Matthiessen, C. M. I. M., \& Painter, C. (2010). Deploying functional grammar. The Commercial Press.

Matthiessen, C. M. I. M. (1995). Lexicogrammatical cartography: English systems. International Language Sciences Publishers.

Mercer, S., \& Kostoulas, A. (Eds.). (2018). Language teacher psychology. Multilingual Matters. https://doi.org/10.21832/mercer9450

Merç, A. (2011). Sources of foreign language student teacher anxiety: A qualitative inquiry. Turkish Online Journal of Qualitative Inquiry, 2(4), 80-94. https://dergipark.org.tr/en/pub/tojqi/issue/21393/229 $\underline{362}$ 
Moors, A., Ellsworth, P. C., Scherer, K. R., \& Frijda, N. H. (2013). Appraisal theories of emotion: State of the art and future development. Emotion Review, 5(2), 119-124.

https://doi.org/10.1177/1754073912468165

Pappa, S., Moate, J., Ruohotie-Lyhty, M., \& Eteläpelto, A. (2017). CLIL teachers in Finland: The role of emotions in professional identity negotiation. Apples-Journal of Applied Language Studies, 11(4), 79-99.

https://doi.org/10.17011/apples/urn.201711144252

Plutchik, R. (1980). Emotion: A psychoevolutionary synthesis. Harper \& Row.

Roseman, I. J. (1984). Cognitive determinants of emotion: A structural theory. In P. Shaver (Ed.), Review of personality and social psychology, Vol. 5: Emotions, relationships, and health (pp. 11-36). SAGE.

Ruohotie-Lyhty, M. (2016). Stories of change and continuity: Understanding the development of identity in foreign language teachers. In P. Kalaja, A Barcelos, M. Aro, \& M. Ruohotie-Lyhty (Eds.), Beliefs, agency and identity in foreign language learning and teaching (pp. 172-201). Palgrave Macmillan. https://doi.org/10.1057/9781137425959_9

Scherer, K. R. (1984). On the nature and function of emotion: A component process approach. In K. R. Scherer, \& P. Ekman (Eds.), Approaches to emotion (pp. 293-318). Lawrence Erlbaum.

Scherer, K. R., Schorr, A., \& Johnstone, T. (2001). Appraisal processes in emotion. Oxford University Press. https://doi.org/10.2307/1423586

Scovel, T. (1978). The effect of affect on foreign language learning: A review of the anxiety research. Language Learning, 28(1), 129-142. https://doi.org/10.1111/j.1467-1770.1978.tb00309.x
Seidman, I. (1991). Interviewing as qualitative research: A guide for researchers in education and the social sciences. Teachers College Press.

Smith, C. A., \& Ellsworth, P. C. (1985). Patterns of cognitive appraisal in emotion. Journal of Personality and Social Psychology, 48(4), 813-838. https://doi.org/10.1037/0022-3514.48.4.813

Smith, C. A., \& Lazarus, R. S. (1990). Emotion and adaptation. Handbook of personality: Theory and research, 609-637.

Smith, C. A., \& Lararus, R. S. (1993). Appraisal components, core relational themes, and the emotions. Cognition and Emotion, 7(3-4), 233-269. https://doi.org/10.1080/02699939308409189

Sutton, R. E., \& Wheatley, K. F. (2003). Teachers' emotions and teaching: A review of the literature and directions for future research. Educational Psychology Review, 15(4), 327-358. https://doi.org/10.1023/a:1026131715856

Tum, D. O. (2014). Foreign language anxiety's forgotten study: The case of the anxious preservice teacher. TESOL Quarterly, 49(4), 627-658. https://doi.org/10.1002/tesq.190

Weiner, B. (1985). An attributional theory of achievement motivation and emotion. Psychological Review, 92(4), 548-573. https://doi.org/10.1037/0033295x.92.4.548

Wolff, D., \& De Costa, P. I. (2017). Expanding the language teacher identity landscape: An investigation of the emotions and strategies of a NNEST. The Modern Language Journal, 101(Supplement 1), 76-90. https://doi.org/10.1111/modl.12370 